\title{
MODEL PEMBELAJARAN MATEMATIKA BERBASIS PENDIDIKAN MULTIKULTURAL
}

\author{
Sri Wulandari Danoebroto \\ PPPPTK Matematika Yogyakarta
}

\begin{abstract}
Abstrak
Indonesia sebagai negara yang multikultur menghadapi persoalan internal berupa melemahnya semangat kebangsaan dan memudarnya nilai-nilai budaya daerah sehingga memicu konflik SARA, ketidakadilan hingga krisis jati diri. Pluralitas bangsa Indonesia disatu sisi memang merupakan kekuatan, namun disisi lain menjadi rentan konflik bila tidak ada kesepahaman, toleransi dan saling pengertian dalam menyikapi perbedaan. Pendidikan multikultural dipandang sangat strategis dalam upaya membangun kesadaran tersebut. Tahap awal yang perlu segera dilakukan adalah penyadaran melalui sosialisasi yang dapat dimulai pada level sekolah, untuk bisa saling mengenal dan memahami keanekaragaman budaya, sehingga menumbuhkan sikap saling menghargai identitas etnik yang sama maupun berbeda. Implementasi pendidikan multikultural di level sekolah tidak dilakukan secara terpisah melainkan terintegrasi dalam mata pelajaran, termasuk matematika. Model pembelajaran matematika berbasis pendidikan multikultural dikembangkan dari lima dimensi pendidikan multikultural James Banks yaitu integrasi budaya dalam konten matematika, konstruksi pengetahuan matematika melalui konteks dan pemahaman budaya, kesetaraan pedagogik, mengurangi prejudice dan memberdayakan kultur sekolah yang kondusif. Pembelajaran matematika berbasis pendidikan multikultural bertujuan untuk mengoptimalkan prestasi belajar matematika sekaligus menumbuhkan kesadaran, kesepahaman, toleransi, saling pengertian dan semangat kebangsaan individu siswa sebagai bagian dari masyarakat yang multikultur.
\end{abstract}

Kata kunci: pembelajaran matematika, ethnomathematics, pendidikan multikultural

\section{A MODEL OF MATEMATICS TEACHING BASED ON MULTICULTURAL EDUCATION}

\begin{abstract}
Indonesia as multicultural country facing internal issues such as weakening the spirit of nationality and waning of cultural values so as to lead to conflict SARA (ethnic, religion, race, group), inequity, and crisis identity. Plurality of Indonesia is powerful but in the other hand become vulnerable to conflict when there is no understanding, tolerance and mutual understanding in facing differences. Multicultural education is considered very strategic to build awareness. The early stages that need to be immediately carried out public awareness through socialization that is can be started at the school level, to get to know each other and to understand cultural diversity, thus fostering mutual respect ethnic identities in the same or different. Implementation of multicultural education at the school level are not done separately but integrated in the subjects, including mathematics. The model of mathematics teaching based on the five dimensions of multicultural education identified by James Banks, including culture integration into mathematics content, knowledge construction of mathematics through context and cultural understanding, equitable pedagogy, prejudice reduction and empowering school culture. Learning mathematics-based multicultural education aims to optimize the achievement of mathematics teaching and fosters awareness, understanding, tolerance, mutual understanding and a spirit of nationality of individual students as part of a multicultural community.
\end{abstract}

Keywords: mathematics learning, ethnomathematics, multicultural education 


\section{PENDAHULUAN}

Indonesia merupakan negara dengan keanekaragaman etnis budaya dan agama. Penduduk Indonesia terdiri atas penduduk asli, keturunan Tionghoa, Arab, dan India, serta golongan orang Indo atau Eurasia yaitu percampuran Indonesia dan Eropa. Penduduk asli Indonesia sendiri terdiri atas lebih dari 300 suku bangsa dengan keunikan identitas budaya serta bahasanya. Ada lima agama besar yaitu Islam, Kristen, Katolik, Hindu dan Budha serta berbagai keyakinan religius etnis tertentu yang dianut masyarakat Indonesia. Bila dilihat dari kondisi geografis Indonesia sebagai negara kepulauan, penduduknya tersebar di pegunungan, wilayah pesisir atau di daratan dengan karakteristik lingkungan yang beragam. Selain itu, pluralitas di Indonesia juga tercipta oleh adanya strata sosial dan ekonomi akibat pertumbuhan ekonomi negara yang belum merata. Hal ini menunjukkan betapa Indonesia adalah negara dengan penduduk yang sangat multikultur.

Dinamika pluralitas di Indonesia tidak hanya terjadi antar penduduk di dalam negeri tetapi juga terjadi antar penduduk Indonesia dengan dunia luar. Indonesia sebagai bagian dari masyarakat dunia tidak mungkin menutup diri terhadap perubahan dan perkembangan yang terjadi. Hal ini tentu berdampak besar bagi eksistensi bangsa Indonesia. Salah satu dampak positifnya adalah terbuka lebar kesempatan untuk mengakses berbagai informasi termasuk penemuan-penemuan terbaru di bidang ilmu pengetahuan. Namun, bangsa Indonesia juga merasakan dampak negatifnya dengan mulai terkikisnya nilai-nilai budaya daerah dan semangat kebangsaan. Hal ini disebabkan oleh terjadinya benturan nilai-nilai kultur yang dianut masyarakat Indonesia dengan nilai-nilai kultur dari luar. Dalam keadaan demikian, seolah-olah bangsa Indonesia menjadi kehilangan jati dirinya.

Diagram berikut menggambarkan interaksi dinamis antar unsur-unsur kultural yang berpengaruh terhadap individu.

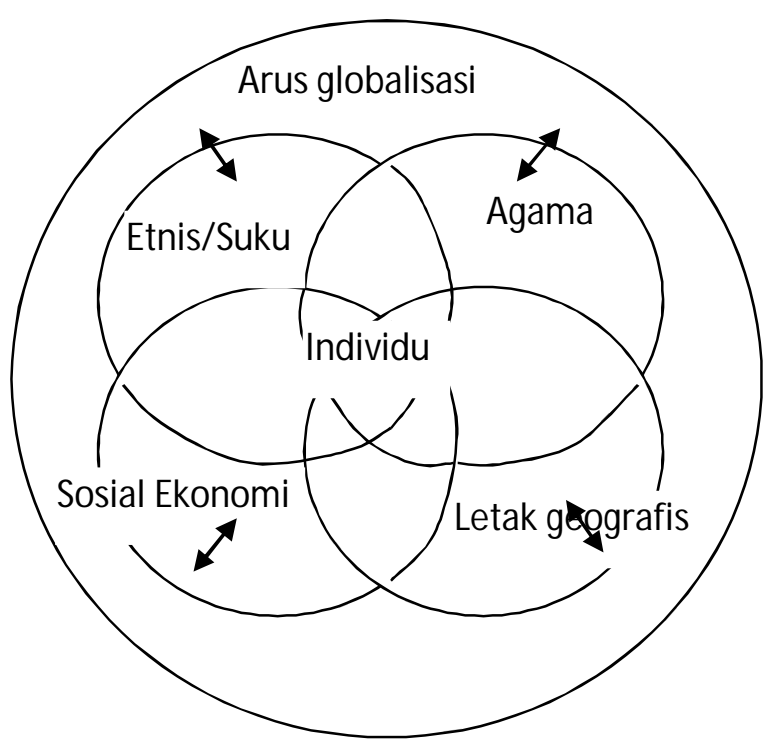

Gambar 1. Interaksi Unsur-Unsur Kultural

Dalam diri individu terdapat unsur etnis atau kesukuan, agama, tingkat sosial ekonomi dan lingkungan tempat tinggal atau letak geografis. Semua unsur ini akan mempengaruhi dan membentuk karakter individu yang akan ditampilkannya dalam sikap, tindakan, perilaku, rasa dan pemikiran. Sebagai bagian dari masyarakat multikultur, performa tersebut dapat berimplikasi positif bila bersifat konstruktif atau berimplikasi negatif bila bersifat destruktif. Interaksi individu dengan individu lainnya dapat menimbulkan saling pengaruh dan percampuran budaya atau sebaliknya saling menolak sehingga menimbulkan konflik. Pengaruh globalisasi yang membawa serta nilai-nilai kultur asing menjadikan semakin kuatnya tarik menarik antar unsur-unsur ini sehingga seolah terjadi 
kontradiksi antara mengikuti perkembangan jaman dengan menjaga identitas diri. Bila individu tercerabut dari akar budaya dan agamanya maka ia mulai kehilangan jati dirinya.

Dengan demikian, pluralitas bukan sesuatu yang statis tetapi bersifat dinamis.

Dinamika pluralitas ini dapat menjadi kekuatan bila didasari oleh kesatuan dan persatuan atau semangat kebangsaan. Menilik dari pengalaman sejarah, Indonesia memiliki semboyan "Bhinneka Tunggal Ika" yang berarti berbeda-beda tetapi tetap satu jua. Pemuda Indonesia dari berbagai suku bangsa menegaskan kesatuan dan persatuan melalui Sumpah Pemuda pada tanggal 28 Oktober 1928. Semua ini merupakan pengalaman historis yang menunjukkan adanya kesadaran dan penerimaan multikultur di Indonesia sekaligus kesadaran akan jati dirinya sebagai bangsa Indonesia. Namun, makna Bhinneka Tunggal Ika ataupun Sumpah Pemuda kini seakan mulai memudar dalam diri bangsa Indonesia. Konflik antar suku, antar agama bahkan pertikaian antar warga yang dipicu oleh hal-hal yang sepele adalah buktinya. Yang lebih memprihatinkan lagi adalah tawuran antar pelajar, antar mahasiswa, baik dengan sesamanya maupun dengan pihak lain, yang sering juga disebabkan oleh kesalahpahaman semata. Padahal pelajar dan mahasiswa adalah gambaran masyarakat terdidik. Apa yang salah dengan pendidikan di Indonesia?

Kemajemukan masyarakat Indonesia dapat dipandang sebagai potensi, namun disisi lain juga rentan menimbulkan konflik. Keanekaragaman yang tidak diikuti dengan kesepahaman, toleransi dan saling pengertian dapat memantikkan api-api konflik yang berdampak pada ketidakadilan. Sementara itu, adalah suatu hal yang mustahil jika keanekaragaman tersebut ditiadakan dengan memaksakan kesamaan atau monokultur. Menurut Koentjaraningrat (2002:46), konsepkonsep multikulturalisme normatif mengatur polarisasi kedua kutub yang kelihatannya kontradiktif, yaitu kesatuan Indonesia di satu pihak dan perbedaan etnis di lain pihak. Hal ini berarti ada dinamika dalam mengembangkan budaya, tradisi, dan bahasa dari masing-masing kelompok etnis sebagai bagian yang integral dari bangsa Indonesia.

Upaya strategis dalam menumbuhkan kesepahaman, toleransi dan saling pengertian adalah melalui pendidikan. Pendidikan yang berpihak pada keanekaragaman dan mengakomodasi perbedaan untuk mencapai tujuan yang sama, yaitu menjadi terdidik, adalah pendidikan multikultural. Pendidikan multikultural merupakan usaha membangun kesadaran diri sebagai individu yang berpotensi dalam memberikan kontribusi positif bagi pembangunan masyarakat. Untuk itu sebagai bagian dari masyarakat yang multikultur, setiap individu perlu menyadari akan identitas dirinya dan menghargai kultur lain yang berbeda dengannya.

Tahap awal yang perlu segera dilakukan adalah penyadaran melalui sosialisasi yang dapat dimulai pada level sekolah, untuk bisa saling mengenal dan memahami keanekaragaman budaya, sehingga menumbuhkan sikap saling menghargai identitas etnik yang sama maupun berbeda. Memang tidak semua permasalahan SARA (Suku, Agama, Ras, dan Antar Golongan) dapat terselesaikan melalui pendidikan multikultural di level sekolah terlebih lagi dalam batasan 
ruang kelas. Akan tetapi, upaya penyadaran itu harus segera dilakukan melalui tindakan nyata. Ruang kelas dipandang cukup efektif sebagai tempat memulainya. Sekolah atau kelas merupakan miniatur masyarakat dimana peserta didik belajar mengembangkan keterampilan sosial dan mengasah pemikiran yang kritis.

Pendidikan multikultural tidak perlu dilakukan secara terpisah atau berdiri sendiri sebagai satu mata pelajaran, melainkan terintegrasi dalam mata pelajaran lain. Beberapa mata pelajaran seperti Pendidikan Kewarganegaraan, Ilmu Pengetahuan Sosial, Agama, Seni Budaya dan Keterampilan maupun mata pelajaran lain yang sejenis dipandang potensial untuk membawa muatan pendidikan multikultural. Lantas bagaimana dengan mata pelajaran matematika?

Dalam pembelajaran matematika itu sendiri juga ditemui masalah ketidakadilan yang disebabkan oleh perbedaan kultur atau akibat dominasi kultur tertentu. Dalam konteks Indonesia, dominasi kultur tidak selalu terjadi oleh golongan mayoritas namun bisa saja oleh golongan minoritas yang memiliki superioritas dalam suatu hal.

Adanya anggapan bahwa siswa dari kelas sosial ekonomi bawah tidak mungkin cerdas sehingga mereka akan sulit mempelajari matematika akan mempengaruhi sikap guru menjadi cenderung tidak adil terhadap siswa tersebut. Dalam hal ini terjadi dominasi kelompok sosial ekonomi tingkat atas dalam pencapaian prestasi matematika. Faktanya, di Indonesia jumlah penduduk miskin justru lebih banyak dibandingkan dengan penduduk kaya.

Adanya anggapan bahwa siswa dari suku atau etnis tertentu, misalnya Cina, memiliki superioritas dalam penguasaan matematika juga berakibat pada ketidakadilan dalam memperlakukan siswa Cina dengan non Cina. Dengan adanya anggapan ini maka siswa non Cina akan merasa dirinya inferior sehingga sulit mencapai prestasi di bidang matematika yang optimal. Faktanya, jumlah penduduk Indonesia non Cina adalah mayoritas dibandingkan dengan penduduk Indonesia dari etnis Cina. Diketahui bahwa suku Jawa adalah kelompok suku terbesar di Indonesia dengan jumlah mencapai $41 \%$ dari total populasi.

Temuan American Association of University Women (Noel, 2000:192) bahwa siswa laki-laki dianggap lebih pandai matematika daripada siswa perempuan juga menimbulkan ketidakadilan ketika siswa lakilaki cenderung mendapatkan dukungan untuk melanjutkan studi di bidang sains teknologi sementara siswa perempuan tidak. Bahkan ketidakadilan itu juga dapat muncul melalui anggapan diantara siswa sendiri bahwa mereka yang pandai matematika biasanya berperilaku aneh dan sulit bergaul, sehingga dijauhi.

Beberapa soal matematika berbentuk soal cerita terkadang mengandung muatan rasisme, misalnya nama orang Jawa lebih sering digunakan daripada nama orang Bali, atau nama orang Jawa yang modern digambarkan sebagai pemilik toko, sementara nama Jawa yang tidak modern digambarkan sebagai petani. Penggambaran tersebut dapat berdampak negatif pada pembentukan konsep diri siswa, khususnya bagi siswa dari kelompok inferior.

Berbagai permasalahan tersebut selanjutnya dapat berdampak pada rendahnya prestasi matematika siswa pada kelompok inferior yaitu siswa dari tingkat sosial ekonomi 
bawah, siswa dari kelompok etnis tertentu, atau siswa perempuan. Penelitian Tate dkk (1997: 46) menunjukkan bahwa pengabaian terhadap keanekaragaman budaya siswa memiliki kontribusi terhadap rendahnya prestasi matematika di kalangan kelompok minoritas. Ketika siswa datang ke sekolah, mereka telah membawa nilai-nilai kultur yang tertanam melalui sosialisasi dalam keluarganya. Apabila guru tidak peka dengan keanekaragaman kultur siswa di kelasnya dan ketika antar siswa kurang peka dengan perbedaan yang ada, maka kondisi ini akan mempersulit siswa dari kelompok minoritas atau kelompok inferior untuk belajar secara optimal.

Matematika merupakan salah satu keterampilan yang dipandang penting untuk dikuasai siswa, sehingga salah satu tujuan pendidikan multikultural adalah membantu mereka agar menguasai keterampilan matematika (Banks, 2002:4). Matematika juga berkontribusi dalam membangun pemikiran yang logis dan kritis. Sebagai ilmu pengetahuan yang mengkaji objek abstrak, seolah-olah matematika termasuk disiplin ilmu yang sedikit berkorelasi dengan budaya. Hal ini menimbulkan anggapan bahwa melakukan integrasi etnik dan konten budaya kedalam mata pelajaran matematika adalah hal yang sulit. Padahal matematika merupakan ilmu pengetahuan yang perkembangannya juga dipengaruhi oleh konteks sosial budaya. Oleh karena itu, sangat mungkin membelajarkan matematika dengan mengintegrasikan nilai-nilai pendidikan multikultural.

Pendidikan multikultural bertujuan untuk mengembangkan identitas etnis siswa agar mereka mengetahui, memahami, menghargai dan menjaga nilai-nilai budaya sesuai etnisnya, sehingga siswa merasa memiliki dan bangga dengan identitas dirinya sebagai etnis tertentu. Selanjutnya, melalui pendidikan multikultural diharapkan siswa dapat mengembangkan hubungan interpersonalnya melalui sikap menghargai, tidak ada kecurigaan atau prasangka terhadap kelompok etnis diluar dirinya sehingga terbangun kesepahaman, toleransi dan saling pengertian. Dengan demikian, melalui pendidikan multikultur diharapkan semua siswa dengan berbagai latarbelakang yang berbeda berkesempatan sama untuk mengembangkan potensi dirinya secara optimal.

Persoalan rendahnya prestasi matematika yang disebabkan oleh pengabaikan multikultur siswa dapat diatasi melalui pembelajaran matematika berbasis pendidikan multikultural. Sejalan dengan itu, upaya menumbuhkan kesadaran, kesepahaman, toleransi, saling pengertian dan semangat kebangsaan dapat dikembangkan melalui pendidikan multikultural yang terintegrasi dalam pembelajaran matematika. Oleh karena itu, penting untuk mengembangkan model pembelajaran matematika yang berbasis pendidikan multikultural. Melalui model pembelajaran ini diharapkan dapat berkembang aspek sosial dan kognitif siswa sekaligus. Stimulasi dapat diberikan melalui integrasi budaya dalam konten matematika sebagai titik awal bagi siswa untuk memunculkan pemikiran yang kritis.

\section{PEMBAHASAN}

\section{Konsep Pendidikan Multikultural}

Menurut Banks (2002: 1-4), pendidikan multikultural merupakan reformasi pendidikan 
yang bertujuan untuk: 1) membantu setiap individu mencapai pemahaman diri yang lebih baik melalui perspektif kultur lainnya, 2) melayani siswa dengan keanekaragaman kultur dan etnik, 3) melayani semua siswa dengan keterampilan, bakat dan pengetahuan yang diperlukan agar dapat berkontribusi bagi dirinya sendiri dan bagi masyarakat yang multikultur, dan 4) membantu siswa untuk menguasai keterampilan penting seperti membaca, menulis dan matematika. Pendidikan multikultural setidaknya mencakup tiga hal berikut: sebuah ide atau konsep, gerakan reformasi pendidikan, dan sebuah proses. Hal yang penting dalam pendidikan multikultural adalah memberi kesempatan bagi siswa dengan karakteristik tertentu untuk mendapat pendidikan yang lebih baik.

Menurut James A. Banks (Zamroni, 2010a:77), pendidikan multikultural meliputi lima dimensi yaitu integrasi konten, konstruksi pengetahuan, kesetaraan pedagogi, reduksi prejudice, dan pemberdayaan kultur sekolah. Dalam integrasi konten, guru menggunakan contoh dan isi materi yang berasal dari berbagai kultur ketika mengajar sehingga merefleksikan keberagaman. Guru membantu siswa memahami melalui penyelidikan bahwa asumsi kultural yang tersirat dalam suatu disiplin ilmu dapat mempengaruhi cara pengetahuan tersebut dikonstruksi. Pendidikan yang setara dapat diupayakan melalui modifikasi cara mengajar agar dapat menfasilitasi siswa dari ras, suku, budaya, gender dan kelas sosial yang berbeda sehingga mencapai prestasi akademis. Kecurigaan antar kelompok siswa dapat dikurangi dengan fokus pada karakteristik perilaku siswa yang rasis, kemudian mencari cara memperbaiki hal itu melalui metode dan materi pengajaran. Sekolah sebagai miniatur masyarakat berperan dalam membangun kultur sekolah yang dapat memberdayakan siswa dari kelompok suku, ras, dan gender yang berbeda.

Kelima dimensi ini terkonseptualisasi dalam perilaku guru, pada pemilihan konten kurikuler multikultural, dalam implementasi pengajaran yang menjadi mediasi multikultural, dan ketika mengkreasi konteks pemberdayaan kelas. Ketika model Banks ditranslasikan kedalam praktek, maka guru membantu siswa mengembangkan keterampilan, pengetahuan, dan nilai yang diperlukan untuk membuat keputusan, mengaktualisasikan tujuan terhadap pengaruh sosial dan perubahan politik. Setidaknya ada tiga dimensi orientasi siswa terhadap pendidikan multikultural, yaitu pengembangan identitas etnik, hubungan interpersonal, dan pemberdayaan diri. Menurut Sheets, ketiga dimensi ini harus dioperasionalkan sebagai dukungan terhadap lima dimensi pendidikan multikultural Banks untuk mengembangkan sosial dan kognitif siswa (Zamroni, 2001a: 77).

Pendidikan multikultural muncul pada keanekaragaman kegiatan belajar, program sekolah, dan latihan/praktek dimana lembaga pendidikan harus tanggap terhadap kebutuhan dan aspirasi dari berbagai kelompok. Berbagai kelompok tersebut mencakup: anak-anak perempuan, kelompok sosial ekonomi lemah, suku minoritas, agama minoritas dan orang cacat. Tantangan yang dihadapi dalam pendidikan multikultural adalah bagaimana membantu siswa dari berbagai kelompok tersebut termediasi antara kultur yang ada di rumah dan masyarakat asalnya dengan kultur 
yang ada di sekolah. Tujuannya agar siswa mencapai kompetensi yang diharapkan, dapat berinteraksi, berkomunikasi dan berpartisipasi efektif dengan kultur yang berbeda di negaranya atau dengan kultur yang berbeda pada masyarakat dunia.

Program kultur merupakan rangkaian program agar siswa dapat beradaptasi dengan lingkungan dimana ia berada. Program tersebut mencakup saling berbagi pengetahuan, konsep dan nilai antar siswa melalui komunikasi, selain itu juga saling memahami keyakinan, simbolsimbol dan interpretasi diantara kelompok. Esensi dari program kultur ini adalah bagaimana tiap anggota kelompok dapat menginterpretasikan dan saling menghormati kultur yang berbeda tersebut.

Mengenali dan memahami peran siswa dalam proses pembelajaran membantu guru mengembangkan keterampilan pedagogis yang dibutuhkan untuk mengevaluasi relevansi kultural dengan isi kurikulum dan keefektifan strategi mengajarnya, dan mengidentifikasi cara siswa mengkonstruk peran, status dan identitasnya dalam kelas yang multikultur. Sebagai hasilnya, siswa berhasil secara akademis, menjaga warisan budaya mereka, mengembangkan identitas etnis, dan menjalani pertemanan yang sehat.

\section{Konsep Pendidikan Matematika}

Konsep pendidikan matematika pada abad 21 berorientasi pada mathematics literacy yaitu kemampuan individu dalam mengidentifikasi dan memahami peran matematika dalam kehidupan, agar mampu membuat keputusan dengan tepat dan memanfaatkan matematika dalam kehidupan sebagai warga negara yang membangun, peduli dan reflektif (OECD, 2003:
19). Oleh karena itu, pembelajaran matematika di kelas hendaknya berorientasi pada pemecahan masalah dan kontekstual. Menurut Yaya (2011, 47), mathematics literacy bersifat kurang formal dan lebih intuitif, kurang abstrak dan lebih kontekstual, kurang simbolik dan lebih cenderung bersifat konkrit, sehingga lebih fokus pada penalaran, membangun pemikiran dan interpretasi.

Dalam melaksanakan konsep pendidikan matematika yang demikian, maka matematika harus dikaitkan dengan hal yang nyata bagi siswa, dan matematika harus dipandang sebagai suatu aktivitas manusia (Gravemeijer, 1994: 82). Siswa mempelajari konsep matematika melalui hal-hal nyata terlebih dahulu sebelum memasuki wilayah matematika yang abstrak. Hal nyata yang dimaksud adalah situasi sehari-hari yang dikenal oleh siswa atau hal-hal yang nyata dalam benak siswa. Hal nyata disini berperan sebagai titik mula pembelajaran, melalui hal-hal yang nyata tersebut, siswa melakukan aktivitas matematisasi. Aktivitas matematisasi merupakan proses pembelajaran yang penting ditempuh oleh siswa. Dalam proses ini, siswa dapat mengonstruksi konsep matematika ke dalam struktur kognitifnya melalui penemuan terbimbing.

Proses matematisasi menempuh dua tahap yaitu proses matematisasi horisontal dan matematisasi vertikal. Dalam matematisasi horisontal, siswa menemukan alat-alat matematis yang dapat membantunya mengorganisasikan dan menyelesaikan masalahmasalah yang ada dalam situasi kehidupan nyata. Dalam matematisasi vertikal terdapat proses pengorganisasian kembali dengan menggunakan sistem matematika itu sendiri. 
Secara sederhana, matematisasi horisontal merupakan pemodelan matematis dari dunia nyata ke dunia simbol matematika. Contoh matematisasi horisontal adalah: pengidentifikasian, perumusan dan pemvisualisasian masalah dengan cara yang berbeda, pentransformasian masalah dunia nyata ke masalah matematika. Sedangkan matematisasi vertikal dapat dipahami sebagai pergerakan dalam dunia simbol matematika. Contoh matematisasi vertikal adalah: merepresentasikan hubungan-hubungan dalam rumus, penyesuaian dengan model matematika, penggunaan model-model yang berbeda, perumusan model matematik dan penggeneralisasian. Dengan demikian, matematisasi berarti membuat situasi non matematis menjadi matematis atau membuat situasi tersebut menjadi lebih matematis. Pada mulanya, siswa melakukan matematisasi horisontal, kemudian dengan bimbingan guru siswa melakukan kegiatan matematisasi vertikal.

Peran guru dalam pembelajaran matematika adalah sebagai fasilitator, sebagai pengorganisir, sebagai pembimbing, dan sebagai evaluator (Gravemeijer, 1994: 90). Guru memberikan masalah kontekstual yang berhubungan dengan topik matematika yang dimaksud sebagai awal pembelajaran. Selama kegiatan pembelajaran baik secara individu atau kelompok, guru berinteraksi sebagai pembimbing dan memberikan bantuan bila diperlukan. Dalam kegiatan diskusi kelas, guru perlu menstimulasi siswa untuk membandingkan beragam solusi yang mereka dapatkan. Siswa berdiskusi untuk menginterpretasikan situasi masalah dan melihat kelayakan serta efisiensi dari berbagai prosedur pemecahan masalah yang mereka dapatkan. Dalam hal ini, siswa berpikir reflektif terhadap apa yang telah mereka lakukan dan hasil yang diperoleh. Guru perlu memberi kebebasan pada siswa untuk memperoleh pemecahannya sendiri, melakukan penemuan sesuai tingkat berpikirnya, dan membangun pengetahuan berdasarkan pengalaman. Guru membantu siswa untuk mengaitkan konsepkonsep matematika yang memang berhubungan dengan topik yang sedang dihadapi saat itu. Guru kemudian membimbing siswa untuk mengembangkan, atau memperluas, atau meningkatkan hasil-hasil pekerjaannya agar menemukan konsep atau prinsip matematika yang lebih rumit.

\section{Strategi Pembelajaran Matematika Berbasis Multikultural}

Salah satu kekuatan yang dibawa siswa ke dalam kelas adalah modal budaya (cultural capital). Secara teoritis, guru dapat menggunakan modal budaya siswa untuk menstimulasi pembelajaran matematika atau malah mengabaikannya, secara aktif memotivasi siswa agar mau belajar atau malah menambah beban untuk berprestasi. Hal ini menunjukkan bahwa guru memiliki peran strategis sebagai agen sosialisasi. Guru dapat menggunakan latarbelakang budaya siswa untuk mengajarkan matematika.

Matematika dan budaya telah dikaji keterhubungannya melalui studi ethnomathematics. Mulai dari sejarah kemunculan suatu teorema matematika hingga simbol-simbol matematika diketahui memiliki kaitan dengan latar belakang budaya tertentu, misalnya angka romawi, angka arab, teorema Pythagoras (Yunani) maupun solusi persamaan kuadrat Al Khwarizmi (Irak). Ide-ide 
matematika telah digunakan di semua budaya pada konteks historis dan kontemporer. Beberapa contoh diantaranya adalah mengintegrasikan konteks ethnomatematikal dalam kehidupan sehari-hari dari masyarakat Brasil untuk membantu siswa memahami matematika sekaligus memahami komunitas masyarakatnya (Averill, et al: 2009). Contoh lain yang menunjukkan hubungan antara matematika dengan budaya adalah Gerdes (1988) yang menunjukkan cara mengembangkan ide geometri Euclidean menggunakan konstruksi geometri yang dikembangkan dari budaya tradisional Mozambik. Indonesia sendiri memiliki kekayaan budaya yang penuh warna, oleh karena itu sangat memungkinkan untuk menggali ethnomathematics yang terkandung didalamnya.

Pembelajaran matematika berbasis pendidikan multikultural dikembangkan berdasarkan lima dimensi pendidikan multikultural James Banks. Kerangka pikir pengembangan model pembelajaran matematika berbasis pendidikan multikultural disajikan dalam skema berikut.

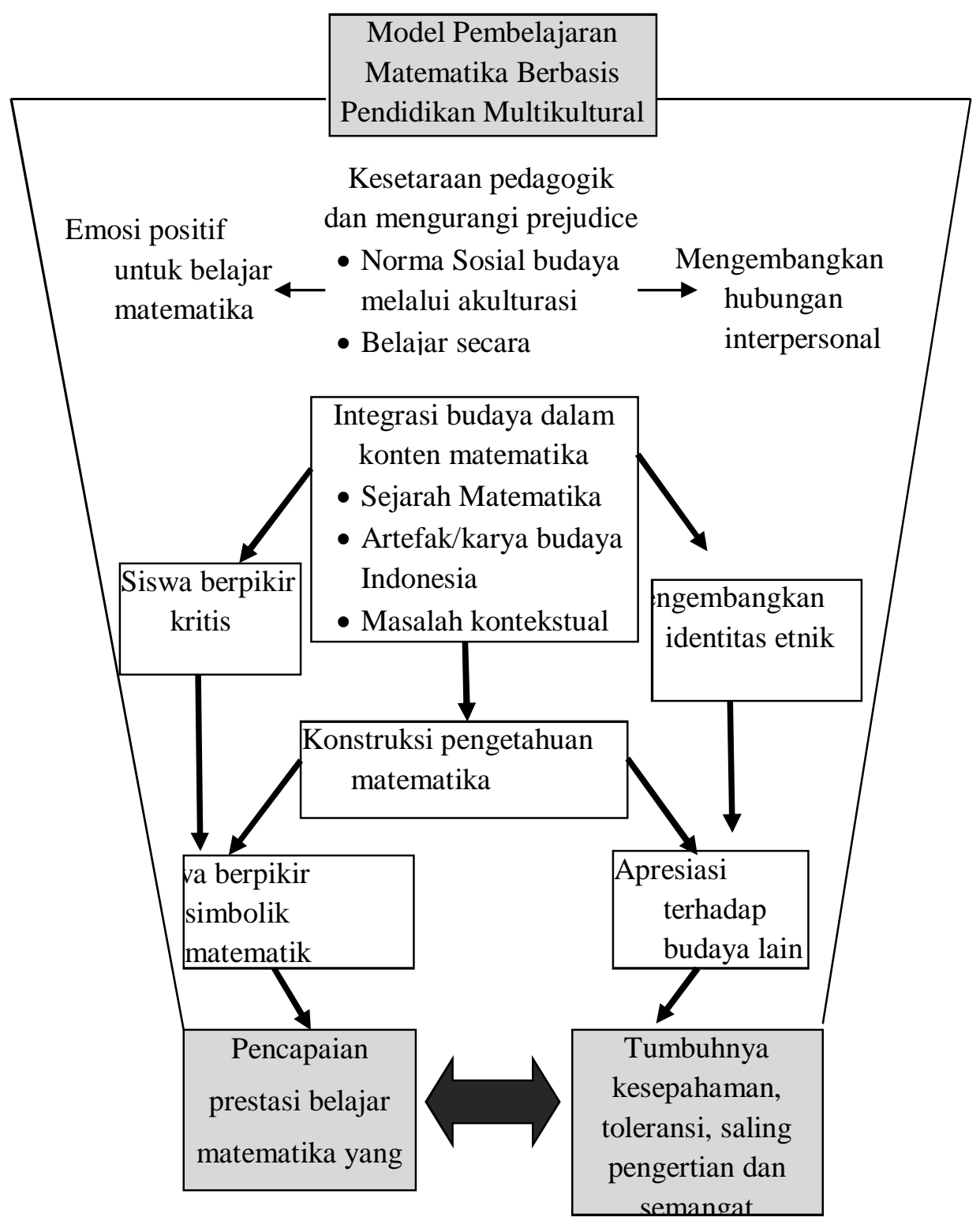

Gambar 2. 
Suatu topik matematika diajarkan melalui konteks beranekaragam budaya daerah di Indonesia melalui ethnomathematics. Eksplorasi muatan konsep matematika dalam tampilan budaya dapat menumbuhkan pengetahuan dan kesadaran siswa bahwa mereka pun dapat berkonstribusi dalam penemuan-penemuan matematika, karena matematika tidak didominasi oleh suatu kultur tertentu. Penggunaan budaya daerah siswa sebagai ilustrasi konsep atau prinsip matematika diharapkan akan memudahkan siswa untuk memahaminya. Selain budaya daerah sendiri, siswa juga mempelajari topik matematika yang sama melalui konteks budaya daerah lainnya. Hal ini bertujuan untuk meningkatkan apresiasi siswa terhadap budaya daerah lainnya di Indonesia. Selain tampilan budaya sebagai ilustrasi konsep atau prinsip matematika, masalah matematika yang kontekstual dapat digunakan sebagai alat untuk memunculkan nilai sosial. Masalah matematika yang mengandung isu ketidaksetaraan atau ketidakadilan dapat menjadi bahan diskusi untuk memancing siswa berpikir kritis dan tumbuh kesadarannya.

Tahap selanjutnya, guru membuka kesempatan bagi siswa untuk mengapresiasi berbagai tampilan budaya atau masalah kontekstual tersebut untuk mencapai pemahaman bahwa suatu konstruksi pengetahuan mengandung asumsi yang menyiratkan budaya tertentu yang mungkin saja bias. Proses rekonstruksi ini ditempuh melalui dua tahap, tahap pertama peserta didik menyusun pengertian matematika dari tampilan budaya atau masalah kontekstual menggunakan simbol-simbol yang dibentuknya sendiri atau simbol matematika non formal. Tahap kedua, guru membimbing peserta didik menyimpulkan pengertian tersebut dalam simbol matematika yang formal.

Setiap siswa dengan latarbelakang kultur yang berbeda harus merasa dapat berkontribusi dan meraih manfaat dari belajar matematika. Untuk itu, siswa harus berpartisipasi dalam pembelajaran matematika di kelas. Hal ini dapat tercapai hanya bila mereka menemukan sebuah jembatan penghubung antara kultur mereka sendiri dengan kultur yang terkandung dalam mata pelajaran matematika yang didapatnya di kelas. Menurut Johnson, A (2010: 126), matematika bukanlah subjek yang netral terhadap budaya. Artinya, matematika yang dikontruksi melalui konteks sosial, budaya dan historis bangsa Indonesia akan mengandung muatan nilai-nilai kebangsaan. Kandungan nilai ini akan terefleksikan dalam proses belajar mengajar melalui kultur yang dibangun oleh guru matematika di dalam kelas. Bila nilai ini sejalan dengan nilai individu peserta didik maka akan terjadi penerimaan dan kesepahaman secara afektif, maka penerimaan dan kesepahaman ini memungkinkan peserta didik untuk memahami konsep matematika secara kognitif.

Selama proses pembelajaran, penting bagi guru untuk mengakomodasi berbagai latar belakang siswanya dengan memberikan perhatian yang sama dan tidak menunjukkan rasisme baik dalam sikap maupun tertulis dalam soal-soal matematika. Pertimbangan strategi pedagogik menghasilkan kelas yang berpusat pada siswa secara fisik, akademik, budaya, dan sosial sehingga siswa mempunyai kesempatan untuk memberdayakan diri. Untuk itu guru perlu 
membangun norma sosial budaya dalam kelas melalui akulturasi.

Bentuk pembelajaran kooperatif dipandang cukup membantu siswa menyesuaikan diri dalam lingkungan budaya yang berbeda, sementara guru juga merasa dimudahkan dalam mengelola pembelajaran hingga siswa menguasai topik matematika tanpa harus melakukan banyak perubahan bentuk dan struktur pengajaran (Sleeter, Christine E, 2004: 171). Upaya mengurangi prejudice diantara siswa dapat dimulai dari pembentukan kelompok diskusi yang heterogen. Heterogenisasi ditinjau dari keragaman gender, tingkat sosial ekonomi, suku, agama. Diskusi dalam kelompok bertujuan menyelesaikan soal matematika, namun disisi lain siswa belajar mengekspresikan dirinya, berpendapat, menerima kritik secara pribadi atau kelompok hingga mencapai pemahaman nilai-nilai sosial. Dengan demikian, mereka belajar mengurangi stereotipe untuk kemudian menjadi aktif berpartisipasi dalam situasi sosial yang saling membutuhkan dan saling menghargai.

Sikap positif terhadap kultur yang berbeda dapat didorong melalui pengkajian isu sosial dan kultur dari perspektif matematika. Data-data statistika dapat mengungkapkan dan menghilangkan stereotipe terhadap suatu kelompok kultur. Misalnya diberikan data siswa berprestasi di satu kecamatan atau kabupaten, kemudian ditelusur latar belakang agama, suku atau etnis, pekerjaan orangtua dan sebagainya dari siswa-siswa tersebut. Guru kemudian mengajak siswa mengkritisi berapa persentase siswa berprestasi yang berasal dari keluarga dengan suku atau etnis tertentu dan seterusnya. Penting bagi guru untuk mengendalikan arah diskusi, bahwa tujuan pencermatan terhadap data-data tersebut selain siswa memahami pengertian rata-rata, modus, atau penyajian data adalah mengeliminir stereotipe terhadap kelompok tertentu.

Data statistik tentang keadaan sosial ekonomi masyarakat pada satu wilayah dapat menjadi stimulan bagi pemikiran kritis. Suatu pemahaman kritis terhadap data numerik mendorong individu untuk mempertanyakan tentang bagaimana masyarakat Indonesia ternyata terkelompok dalam struktur sosial ekonomi. Kemudian, yang terpenting adalah memungkinkan mereka memikirkan tindakan yang akan mereka lakukan sebagai pihak yang berada pada tingkatan sosial ekonomi lebih tinggi.

Indonesia adalah negara yang kaya dengan budaya. Guru dapat memanfaatkan budaya daerah semisal artefak atau hasil karya seni daerah yang mengandung unsur matematis sebagai sarana mengajarkan suatu konsep atau prinsip matematika. Sebagai contoh, pola bentuk pada motif batik dapat menjadi alternatif sumber belajar matematika bagi siswa. Bentuk geometri yang dapat dijumpai pada batik berupa titik, garis dan bidang datar. Bidang datar tersebut misalnya lingkaran, elips, segiempat dan sebagainya. Bentukan artistik pada batik dihasilkan melalui transformasi titik, garis atau bidang datar tersebut melalui translasi (pergeseran), rotasi (perputaran), refleksi (pencerminan) atau dilatasi (perkalian). Guru menggunakan contoh batik sebagai ilustrasi prinsip geometri transformasi, kemudian siswa diminta mencermati dan menyelidiki bentuk atau gambar dalam batik yang menunjukkan prinsip geometri transformasi. 
Selain siswa memperoleh pengetahuan terkait konsep geometri transformasi, mereka juga memahami aplikasi geometri transformasi yang dapat menghasilkan karya seni. Sejalan dengan ini, melalui penyelidikan pola bentuk motif batik, diharapkan siswa semakin mengapresiasi karya seni bangsanya sendiri sehingga menumbuhkan rasa cinta tanah air, dapat menginterpretasikan dan saling menghormati kultur yang berbeda diantara mereka.

Ide matematika lain yang dapat dijumpai pada ornamen batik adalah bentuk fraktal. Fraktal merupakan himpunan tak hingga yang terbentuk melalui proses iterasi yang algoritmik. Guru kemudian meminta siswa mencermati motif fraktal, mendiskusikan beberapa prosedur etnomatematikal dan melakukan eksplorasi terhadap metode-metode tersebut. Siswa diberi kebebasan untuk mengkonstruksi algoritmanya sendiri, kemudian guru melakukan validasi atas algoritma temuan siswa tersebut. Hal ini penting untuk menumbuhkan harga diri dan kepercayaan diri bahwa mereka mampu mengerjakan soal matematika. Di sisi lain, temuan algoritma yang didasarkan pada pengalaman nyata yang mengandung nilai sosial dan konstruksi pengetahuan matematika oleh siswa sendiri akan menjadikan matematika lebih bermakna bagi mereka.

Pembelajaran aljabar dapat dilakukan melalui pengkajian sejarah matematika di beberapa tempat. Sebagai contoh, beberapa pembuktian teorema Pythagoras ditemukan di beberapa negara yang terpisah seperti Babylonia, China dan India. Guru dapat meminta siswa mempelajari masing-masing bentuk pembuktian kemudian mendiskusikan bagaimana matematikawan yang berbeda kultur dapat berpikir tentang ide yang sama, yaitu teorema Pythagoras, tetapi melalui beberapa cara yang berbeda.

Mempertimbangkan konteks sosial budaya termasuk nilai-nilai yang terkandung didalamnya menjadi nilai tambah secara kognitif dan afektif guna memperdalam pemahaman siswa terhadap pembelajaran matematika. Namun sejalan dengan itu, siswa mendapatkan pencerahan dan penyadaran mengenai keberadaannya sebagai suatu etnis, suatu kelas sosial ekonomi, suatu agama ditengah-tengah masyarakat yang berbeda etnis, kelas sosial ekonomi dan agama. Setiap individu memiliki karakteristik unik dan sekaligus kesamaan sebagai manusia ciptaan Tuhan.

\section{KESIMPULAN}

1. Keanekaragaman budaya bangsa Indonesia hendaknya dipandang sebagai kekuatan pembangunan, adapun titik-titik kelemahan yang rentan konflik dijembatani melalui upaya membangun kesadaran, kesepahaman, toleransi dan saling pengertian melalui pendidikan multikultural.

2. Praksis pendidikan multikultural di level sekolah dilakukan melalui integrasi nilainilai pendidikan multikultur dalam mata pelajaran, termasuk dalam mata pelajaran matematika.

3. Rendahnya prestasi matematika siswa yang disebabkan oleh pengabaian terhadap kultur dapat diatasi dengan mengintegrasikan nilai-nilai pendidikan multikultur dalam pembelajaran matematika. 
4. Pembelajaran matematika berbasis pendidikan multikultural bertujuan untuk mengoptimalkan prestasi belajar matematika sekaligus menumbuhkan kesadaran, kesepahaman, toleransi, saling pengertian dan semangat kebangsaan individu siswa sebagai bagian dari masyarakat yang multikultur.

5. Model pembelajaran matematika berbasis pendidikan multikultural dikembangkan melalui integrasi konten yang dieksplorasi dari kekayaan budaya daerah, menggunakan konteks multikultur dalam mengilustrasikan konsep atau prinsip matematika. Misalnya artefak seni budaya (batik, fraktal) atau sejarah matematika untuk mengajarkan geometri atau aljabar, masalah kontekstual tentang realitas multikultur dalam bentuk soal cerita yang anti rasis, data statistika yang faktual misalnya tentang kondisi sosial ekonomi masyarakat di sekitar siswa.

6. konstruksi pengetahuan matematika melalui konteks multikultur bertujuan untuk:
a) memudahkan siswa dengan latarbelakang kultur yang berbeda- beda dalam memahami konsep atau prinsip matematika,
b) mendorong pemikiran matematis yang kreatif,
c) memunculkan apresiasi pada kultur yang berbeda,
d) mendorong pemikiran kritis terhadap realitas yang multikultur
e) mengasah kepekaan sosial.

7. Guru menggunakan strategi mengajar yang memungkinkan terjadi dialog antar siswa atau berdiskusi untuk menjalin kesepahaman dan pengertian ketika mengkonstruksi pengetahuan matematika dan saling tolong menolong (metode kooperatif)

8. Guru mengembangkan norma sosial budaya dalam kelas melalui proses akulturasi dalam rangka mengurangi prejudice dan membangun kultur sekolah yang kondusif agar semua siswa dapat berprestasi dengan optimal

\section{DAFTAR PUSTAKA}

Averill, et al. (2009). Culturally Responsive Teaching of Mathematics: Three Models from Linked Studies. Jurnal for Research in Mathematics Education. Vol 40 No 2, hal 157-186

Banks, James A. (2002). An introduction to multicultural education. Boston: Allyn and Bacon.

Gerdes, P. (1988). On culture, geometrical thinking and mathematics education. Educational Studies in Mathematics. 19 hal 137-162.

Johnson, A. (2010). Teaching mathematics to culturally and linguistically diverse learners. New York: Pearson Education Inc.

Koentjaraningrat. (2002). Antropologi Indonesia. Jakarta: Penerbit Djambatan, cetakan kesepuluh.

Noel, Jana. (2000). Notabel selection in multicultural education. San Fransisco, CA: Mc-Graw Hill.

OECD. (2003). The PISA 2003 Assessment framework-Mathematics, Reading, Science and Problem Solving Knowledge and Skills. Paris: OECD.

Sleeter, Christine E. (2004). How white teacher construct race. Dalam Ladson-Billings, Gloria \& Gilborn, David (Eds). The routledgeFalmer reader in multicultural education (hal 163-177). London: RoutledgeFalmer Taylor \& Francis Group.

Tate, W.F. (1997). Race-ethnicity, SES, gender, and language proficiency trends in 
mathematics achievement: An update. Journal for Research in Mathematics Education, 28. hal 652-680.

Yaya S. Kusumah. (2011). Mathematical literacy. Proceedings $1^{\text {st }}$ International Symposium on Mathematics Education innovation. $18 \quad-19 \quad$ November 2011 Yogyakarta, p 45-52.

Zamroni. (2010a). The implementation of multicultural education: A reader. Yogyakarta: The Graduate Program The State University of Yogyakarta. 